\title{
The Periurethral Glandular Complex in the Water Buffalo: An Ultrastructural, Histological and Lectin-Histochemical Study
}

\author{
Ahmed Abou-ElmagD* and Karl-Heinz WrobeL \\ Institute of Anatomy, University of Regensburg, Regensburg, Federal Republic of Germany
}

Received May 2, 1989

\begin{abstract}
Summary. The periurethral glandular complex of the male water buffalo consists of a prostate body (not always present), a disseminate prostate and paired bulbourethral glands. The epithelium contains two types of columnar secretory cells and occasional basal cells. Type I secretory cells produce glycoprotein with a wide range of terminal sugars, these cells dominate in the cranial region of the periurethral glandular complex, whereas Type II secretory cells elaborate a mixture of carboxylated and sulphated sialomucin and prevail in the caudal portions of the periurethral glandular complex. At the ultrastructural level, Type I cells display a characteristic localization of organelles: a round nucleus in the basal portion, a Golgi apparatus and rough endoplasmic reticulum in the middle third, and secretory granules in the apical portion. Type II cells possess the ultrastructure of typical mucous cells. Following perfusion fixation of the epithelium, modifications of the lateral plasmalemmata are very obvious forming apicolateral secretory canaliculi, an intercellular channel system and a basolateral labyrinth. Nerve fibers surround the glandular basal lamina. Occasionally axons, probably of cholinergic nature, penetrate the basal lamina, then terminate in the intercellular clefts or form intraepithelial neuroglandular contacts.
\end{abstract}

The reproduction process of the water buffalo is of considerable economic and biological interest, especially for tropical and subtropical regions where its domesfication is integral to the society. Therefore a better understanding of the morphology and function of the reproductive organs in this ruminant species is highly desirable. This study deals with the periurethral glands which are derived from the epithelium of the urogenital sinus and differentiate into the prostate and bulbourethral glands. According to macroscopical and light microscopical observations, three separate glandular structures can be described in the water buffalo (OSMAN, 1965; FAHMY and OSMAN, 1972; EISSA, 1980; MouSSA et al., 1983): the prostate body (pars externa), disseminate prostate (pars interna) and paired bulbourethral glands. The body of the prostate is a complex of glands covering the dorsal aspect of the cranial pelvic urethra. It is not always present macroscopically. The disseminate prostate is a comprehensive name for a layer of individual glands surrounding the entire pelvic urethra. Paired bulbourethral glands are found in dorsolateral location at the caudal end of the pelvic urethra.

The functional significance of the secretions of this periurethral glandular complex for ruminant reproduction is poorly understood. Carbohydrates are a main constituent of the glandular secretion (YAMADA and SHIMIZU, 1977; TSUKISE and YAMADA, 1984, 1987 a, b). According to EISSA (1980) the prostate and bulbourethral glands contribute fructose to the seminal fluid.

We hope that a better knowledge of ultrastructure and carbohydrate histochemistry of the prostate and bulbourethral glands will facilitate future physiological studies and functional interpretations of these accessory glands of reproduction.

*Ahmed ABou-Elmagd was supported by the Egyptian Study Mission during his work in Regensburg. Permanent address: Department of Histology and Anatomy, Faculty of Veterinary Medicine, University of Assiut, Egypt. 


\section{MATERIALS AND METHODS}

The pelvic urethra together with its undamaged surroundings was removed from 12 male water buffaloes (age $\sim 2$ years) immediately after slaughter in Assiut (Egypt) abattoir. The local supplying arteries (Aa. prostaticae) were canulated, and a rinsing fluid (for composition see WROBEL et al., 1978) was injected to clear the vascular system. After rinsing, a perfusion fixation of the entire pelvic urethra and its attached glands was performed. Tissue blocks representing the body of the prostate, cranial, middle and caudal regions of the disseminate prostate and bulbourethral glands were removed for examination.

For light microscopical studies, perfusion with Bouin's solution was performed. From a paraplastembedded material 5-7 $\mu \mathrm{m}$ thick sections were prepared and stained with a modified Masson-Goldner sequence, alcian blue at $\mathrm{pH} 2.5$ (without and after neuraminidase digestion), alcian blue at $\mathrm{pH} 0.5$, PAS reaction (without and after diastase digestion), PASalcian blue ( $\mathrm{pH} 2.5)$ sequence, aldehyde fuchsin-alcian blue ( $\mathrm{pH} 2.5)$, ponceau $2 \mathrm{R}$ and ninhydrin-Schiff stains.

For transmission electron microscopical study, perfusion-fixation was performed with the formaldehyde-glutaraldehyde fixative as described by KARNOVSKY (1965). Small pieces of the periurethral glands were separated and washed in $0.2 \mathrm{M}$ cacodylate buffer. After osmication $\left(1 \% \mathrm{OsO}_{4}\right)$ the blocks were dehydrated in graded ethanol and embedded in ERL 4206 (SPURR, 1969). Semithin sections were stained with methylene blue-azur II or PASalcian blue. Ultrathin sections were mounted on copper grids, stained with uranyl acetate and lead citrate (REYNOLDS, 1963) and examined with a Zeiss EM 10 A electron microscope.
For lectin-histochemical examination, Bouin-fixed paraplast-embedded sections $(5-7 \mu \mathrm{m}$ thick) were stained with 10 different FITC-conjugated lectins (Table 1), according to DORN and BERNSTEIN (1983) and examined in a fluorescence microscope.

\section{RESULTS}

\section{Light microscopy}

Both the prostate body and disseminate prostate comprise separate tubuloalveolar glands which open with excretory ducts into the pelvic urethra. A dense connective tissue with occasional smooth muscle fibers constitutes the periglandular stroma and divides the parenchyma into lobes. A network of elastic fibers surrounds the glandular end pieces (Fig. 4). The shape and size of the secretory elements are irregular; in the body, wide glandular saccules dominate, whereas in the disseminate prostate, narrow tubules prevail. In the bulbourethral glands, tubuloalveolar end pieces and tubular ducts, partly dilated to form cyst-like storing cavities, are most obvious.

The secretory epithelium of both portions of the prostate and of bulbourethral glands is similar, consisting of tall columnar cells with a spherical or flattened nucleus in the basal position and accumulations of secretory granules in an apical location (Figs. $1-3,5,6)$. A certain number of cells are low columnar in shape and lack secretory granules, thus reflecting a secretory cycle with different phases of cellular activity.

In the prostate epithelium, small basal cells with centrally located relatively large oval nuclei can be easily identified (Fig. 1), but are scarce in the bulbourethral gland. The secretory material stored within

Fig. 1. Secretory epithelium of the disseminate prostate. Occasional basal cells (arrows) are easily identified. Semithin section, methylene blue-azur II, $\times 350$

Fig. 2. Secretory epithelium of the disseminate prostate. A region with Type I glandular cells with apical granules, reacting exclusively with PAS. Semithin section, PAS-alcian blue, $\times 350$

Fig. 3. Secretory epithelium of the disseminate prostate. A region with Type II glandular cells with granules, reacting with both PAS and alcian blue. Semithin section, $\times 350$

Fig. 4. The connective tissue between prostatic glandular end pieces (empty spaces) contains a network of elastic fibers, best seen when the end piece wall is cut tangentially (middle). Aldehyde fuchsin-alcian blue, $\times 350$

Fig. 5. Bulbourethral Type II glandular cells with flattened basal nuclei assume a foamy appearance due to abundant secretory material. A secretion collecting space (SCS) and two end pieces with Type I glandular cells (asterisks) are also seen. Semithin section, methylene blue-azur II, $\times 350$

Fig. 6. Type II glandular cells of bulbourethral end pieces stained intensely with both PAS and alcian blue (pH 2.5). Flattened basal nuclei can be identified as white dots. $\times 140$ 

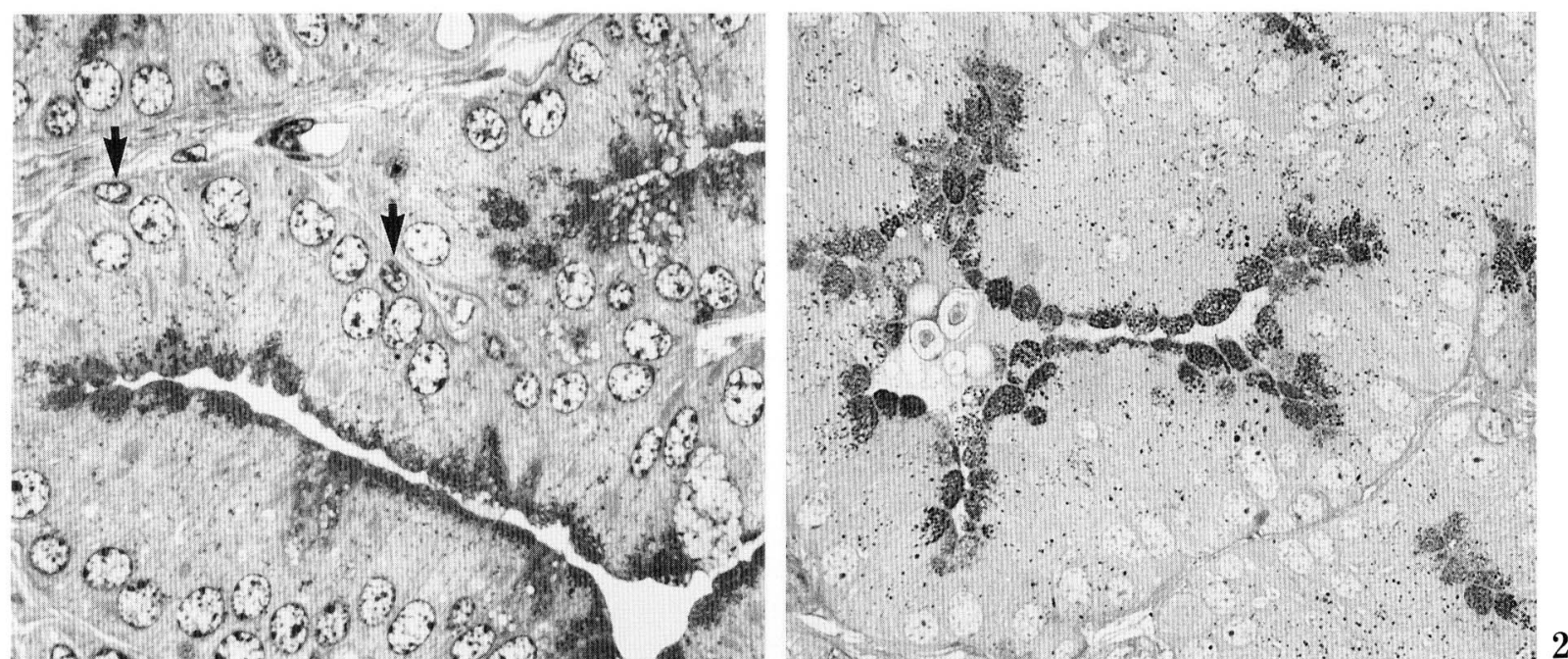

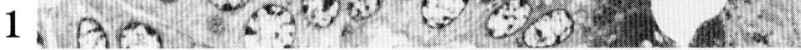
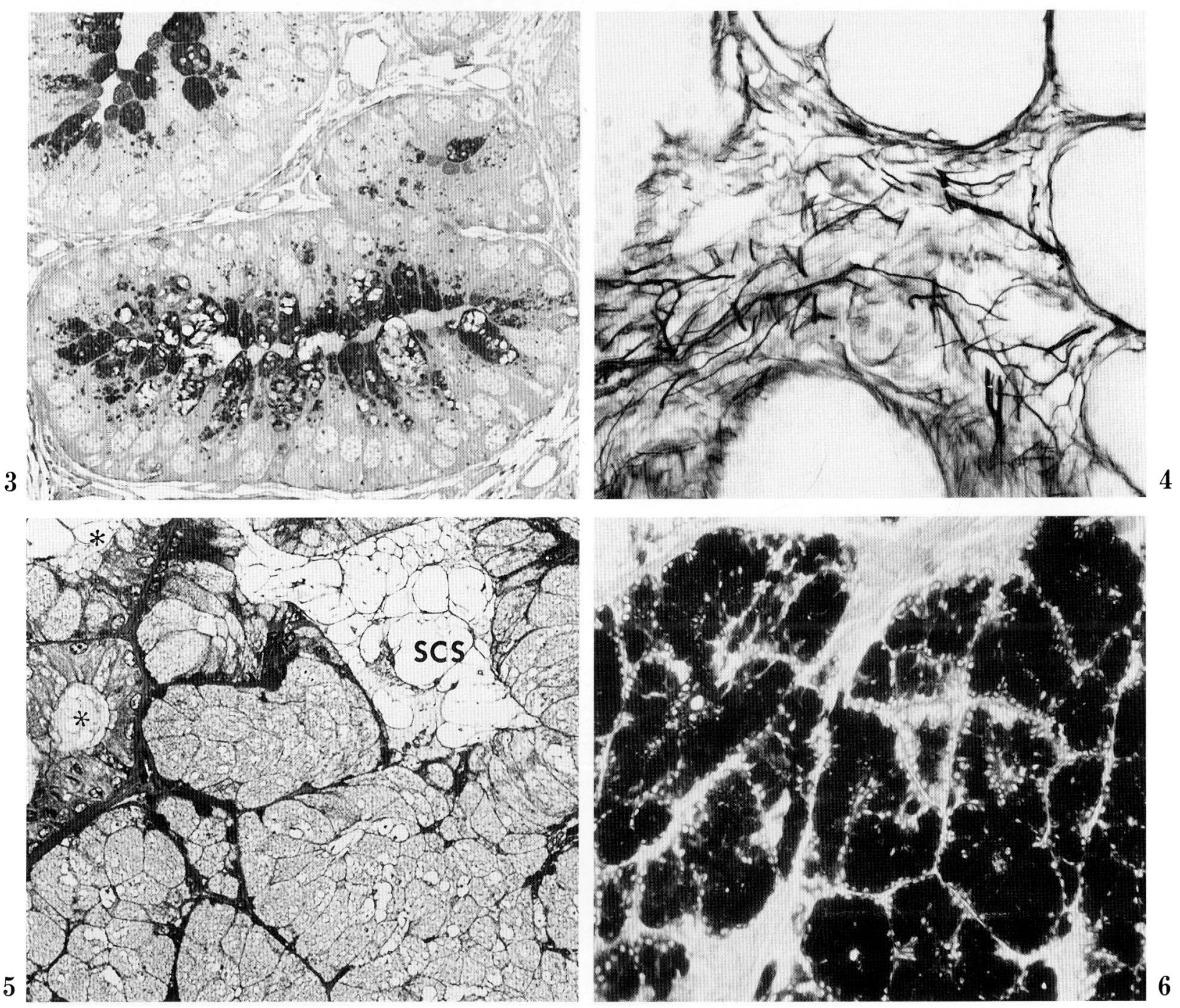

Figs. 1-6. Legends on the opposite page. 
Table 1. Specific and corresponding inhibitory sugars for applied lectins

\begin{tabular}{|c|c|c|c|}
\hline Lectin & Source & Specific sugar & Inhibitory sugar \\
\hline Con A & Canavalia ensiformis & $\alpha$-D-Glc, $\alpha$-Man & $\alpha$-Me-Man \\
\hline DBA & Dolichos biflorus & $\alpha$-NacGal & D-NacGal \\
\hline SBA & Glycine $\max$ & $\alpha / \beta$-D-Gal, $\alpha$-NacGal & D-NacGal \\
\hline RCA I & Ricinus communis & $\beta$-D-Gal & D-Gal \\
\hline WGA & Triticum vulgare & $\alpha /$ B-D-NacGlc, NacNeu & D-NacGlc \\
\hline UEA I & Ulex europaeus & $\alpha$-L-Fucose & L-Fucose \\
\hline PNA & Arachis hypogaea & D-Gal, D-NacGal & D-Gal \\
\hline $\begin{array}{l}\text { GSA I } \\
\text { GSA II }\end{array}$ & Griffonia simplicifolia & $\begin{array}{l}\alpha-\mathrm{Gal} \\
\alpha-/ \beta \text {-D-NacGlc }\end{array}$ & D-Gal \\
\hline MPA & Maclura pomifera & $\alpha-\mathrm{D}-\mathrm{Gal}$ & D-NacGal \\
\hline
\end{tabular}

Man: mannose, Glc: glucose, Gal: galactose, Nac: N-acetyl, Neu: neuraminic acid, Me: methyl

the glandular collecting cavities and saccules has a granular appearance.

Carbohydrate and protein histochemistry underlines the similarity of the prostate to the bulbourethral secretory epithelium. After application of the PAS-alcian blue ( $\mathrm{pH} 2.5)$ sequence in the entire períurethral glandular complex two types of secretory cells were distinguished: cells (Fig. 2) contaning apical granules that react exclusively with PAS (Type I cells) and cells (Fig. 3) possessing secretory material giving a positive reaction with both PAS and alcian blue ( $\mathrm{pH} 2.5)$, thus appearing violet (Type II cells).

Type I cells constitute most of the secretory end pieces in the body of the prostate as well as in the cranial and middle thirds of the disseminate prostatic layer. A reduced number of Type I cells are found in the caudal third of the disseminate prostate and in the bulbourethral epithelium. In the latter gland (Fig. 5) they prefer a position near the ductular collecting cavities. The granules of Type I cells are relatively small and are concentrated in the apical region, though occasionally in the perinuclear region. The PAS reaction is not affected by diastase digestion.
Furthermore, Type I cell granules give positive results with ponceau $2 \mathrm{R}$ and ninhydrin-Schiff stains, they thus contain a glycoprotein.

Type II cells constitute the majority of end pieces in the disseminate prostate around the caudal third of the pelvic urethra, and dominate within the bulbourethral epithelium (Figs. 5, 6). Type II cells are scarce in the body of the prostate and in the disseminate prostate surrounding the cranial two thirds of the pelvic urethra. The secretory material of Type II cells appears in the form of distinct granules in the apical cell region (Fig. 3) or as a foamy mucous substance (Fig. 5) filling most of the cell. The shape and location of the nucleus correspond to the amount of the stored secretory material. Spherical nuclei in the basal third are observed in cells with distinct apical granules (Figs. 1, 3). Flattended, dense nuclei are located close to the basal plasma membrane in cells with abundant secretory material (Figs. 5, 6). The latter situation dominates in the bulbourethral epithelium. The secretory material of Type II cells is poorly stained with alcian blue at $\mathrm{pH} 0.5$. The alcian blue reaction at $\mathrm{pH} 2.5$ is diminished following neuraminidase digestion. After application of the alde-

Fig. 7. Type I secretory cells of the prostate. Note the characteristic tripartition of the cells with a basal nucleus and apical accumulation of secretory granules, whereas the Golgi apparatus $(G)$ and the majority of other organelles are located in the middle third. The apicolateral, lateral and basolateral intercellular canaliculi are indicated by asterisks, desmosome-mitochondria complexes by arrowheads. A differentiated basal cell ( $B C$ ) with a kidney-shaped nucleus and basally oriented Golgi apparatus $(G)$ is also seen, $\times 9,100$ 


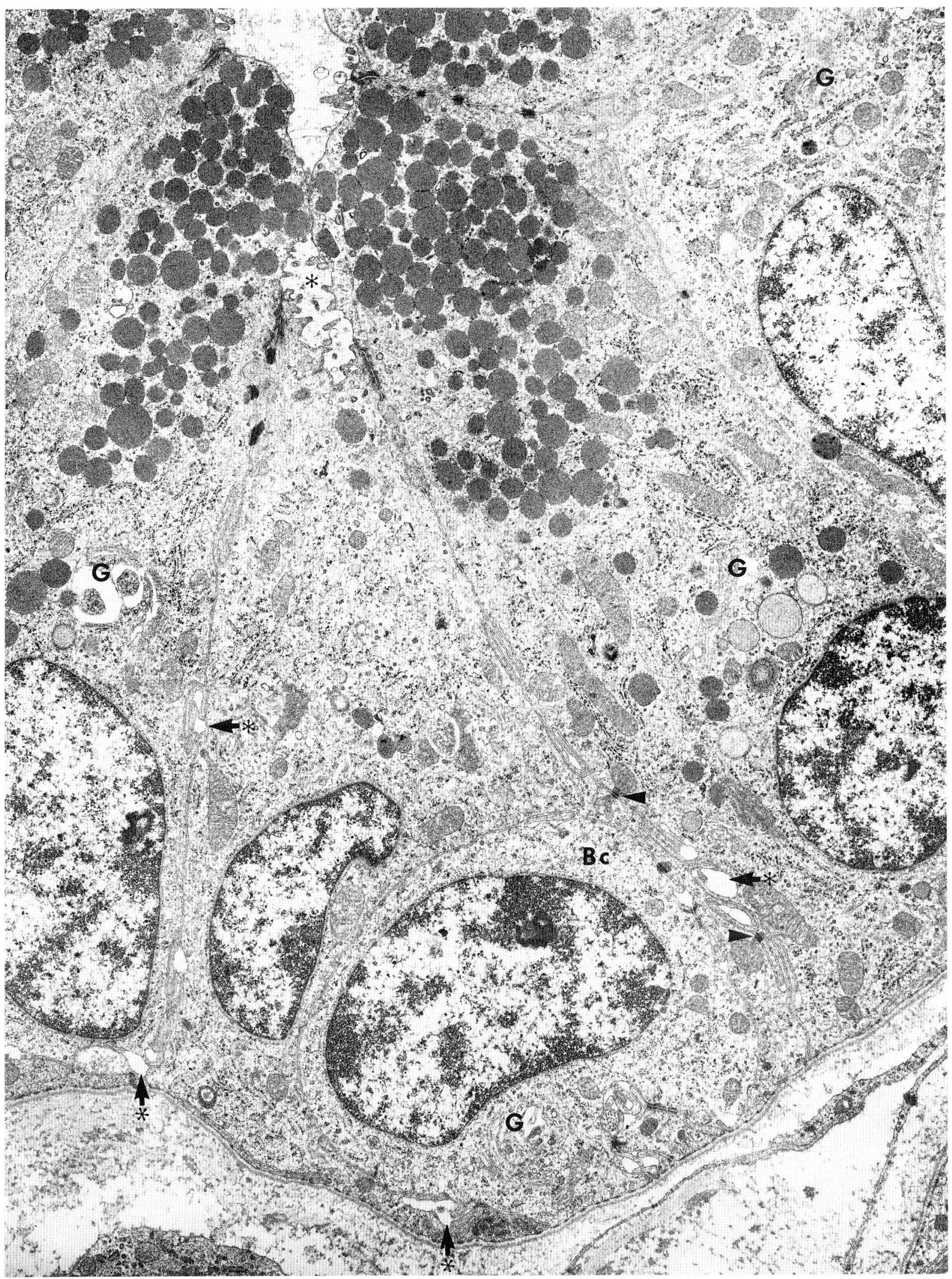

Fig. 7. Legend on the opposite page. 
hyde fuchsin-alcian blue $(\mathrm{pH} 2.5)$ sequence, Type II cells can be further differentiated. The majority reacts with both aldehyde fuchsin and alcian blue and appears dark violet. A small number of cells contain granules which react only with aldehyde fuchsin, and a few cells have granules with exclusive alcian blue reactivity. Diastase digestion does not reduce the PAS staining of the secretory material. From these observations, we conclude that most of the Type II cells of the prostate and bulbourethral glands contain a mixture of carboxylated and sulphated sialomucin as secretory material. Some cells contain only carboxylated sialomucin. A small minority reveals the reaction of an intensely sulphated epithelial mucin.

\section{Electron microscopy}

\section{The ultrastructure of Type I glandular cells (Fig. 7)}

Type I cells of the periurethral glandular complex display modifications of their plasmalemmata and intercellular spaces in order to variously increase the efficiency of intercellular transport and secretion. The apical free surface exhibits short microvilli, which project frequently into apicolateral intercellular secretory canaliculi. At certain sites the intercellular space enlarges to form an intercellular channel system for transport and exchange between adjacent cells. Furthermore, adjacent cells develop many interdigitating cytoplasmic processes. In the basolateral position, the intercellular space is again enlarged to form a labyrinthine system which remains open to the stroma but is sealed against the intercellular cleft. Desmosomes connecting the epithelial cells appear frequently in close association with mitochondria to form mitochondria-desmosome complexes. Such complexes are observed as attachments above the basolateral labyrinthine system and as sealing devices for intercellular transport and exchange canaliculi. The basal surface of Type I cells is generally smooth and unspecialized. Many hemidesmosomes connect the cells with the underlying basal lamina.

In most Type I cells, cytoplasm and organelles show a characteristic organization (Figs. 7, 8). The round or oval nucleus is placed in the basal third, a Golgi apparatus, rough endoplasmic reticulum and the majority of mitochondria occupy the middle third, and the secretory granules are located in the apical cell region.

The secretory granules of Type I cells are spherical in shape, are surrounded by a limiting membrane, and contain electron dense homogeneous material, which is released by a process of exocytosis.

\section{The ultrastructure of Type II glandular cells (Fig. 9)}

Type II cells show ultrastructural features of typical mucous cells. Their granules contain flocculent, filamentous or granulated material of varying electron density. Some granules display a dense core and a lighter periphery. Prior to extrusion the granules tend to coalesce near the apical cell surface.

Two types of basal cells are distinguished in the prostate and bulbourethral glands (Figs. 7, 11). The first one (Fig. 11) is undifferentiated, has a centrally located nucleus and few other organelles. The second type (Fig. 7) is higher developed, possesses a kidneyshaped nucleus, an basally located active Golgi apparatus and round or oval mitochondria. Small desmosomes connect both types of basal cells with adjacent secretory cells.

Free mononuclear cells are often observed within the epithelium of the prostate. They are identified as lymphocytes, monocytes or macrophages and are usually found near the basal lamina.

The interglandular stroma is also rich in free mononuclear cells, particularly plasma and mast cells. Blood vessels and capillaries are found around the glandular end pieces. Non-myelinated nerve fibers accompany the blood vessels and are surrounded by

Fig. 8. Supranuclear region of a Type I secretory cell with typical Golgi apparatus $(G)$ and parallel stacks of rough endoplasmic reticulum. $\times 19,000$

Fig. 9. Type II secretory cells of bulbourethral gland. Type II cells are morphologically typical mucous cells. Note the heterogeneity of secretory granules; some possess a dense core, while some merge into larger complexes prior to extrusion. $L$ glandular lumen. $\times 5,000$

Fig. 10. Part of the basolateral labyrinthine intercellular exchange system (asterisk) which is apically sealed by a desmosome but remains open to the basal lamina $(B l)$. Arrow indicates intercellular intraepithelial nerve fiber. $\times 18,200$

Fig. 11. Undifferentiated basal cell of the prostatic epithelium. Note that basal cells also participate in the formation of the basolateral intercellular exchange system (arrows). Desmosomes (arrowhead) connect basal and secretory cells. $\times 7,300$ 

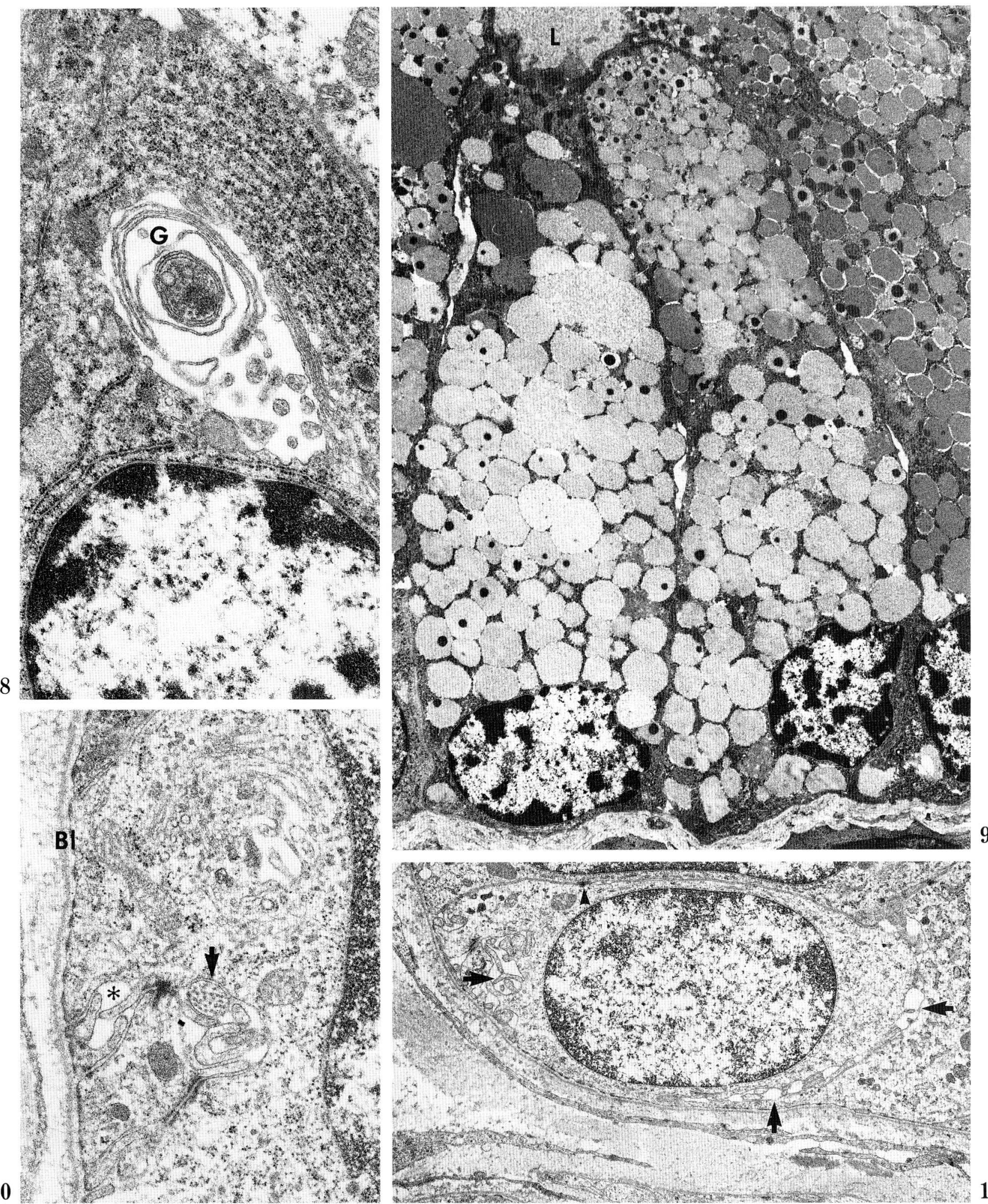
Schwann's cells. Occasionally, nerve fibers form dense networks on the outer surface of the glandular basal lamina (Fig. 12a); they also penetrate the basal lamina (Figs. 10, 12b), occasionally forming intraepithelial neuroglandular contacts. Such intraepithelial nerve fibers and terminals are exclusively identified in the prostate. Subepithelial and intraepithelial terminals contain accumulations of small agranular vesicles, and a few larger dense granules 80-100 $\mu \mathrm{m}$ in diameter (Figs. 12a, b).

\section{Lectin-histochemistry (Table 2)}

FITC-labeled lectins react characteristically with the secretory cells of the periurethral glandular complex (Figs. 13-18). In the prostate the mucous granules of Type II cells display varying affinities for all applicated lectins, but in those of the bulbourethral glands no reaction was obtained with Con A agglutinin (specific for $\alpha$-D-Glc/Man), DBA agglutinin (specific for $\alpha$ $\mathrm{NacGal}$ ) and RCA I agglutinin (specific for $\beta$-D-Gal).
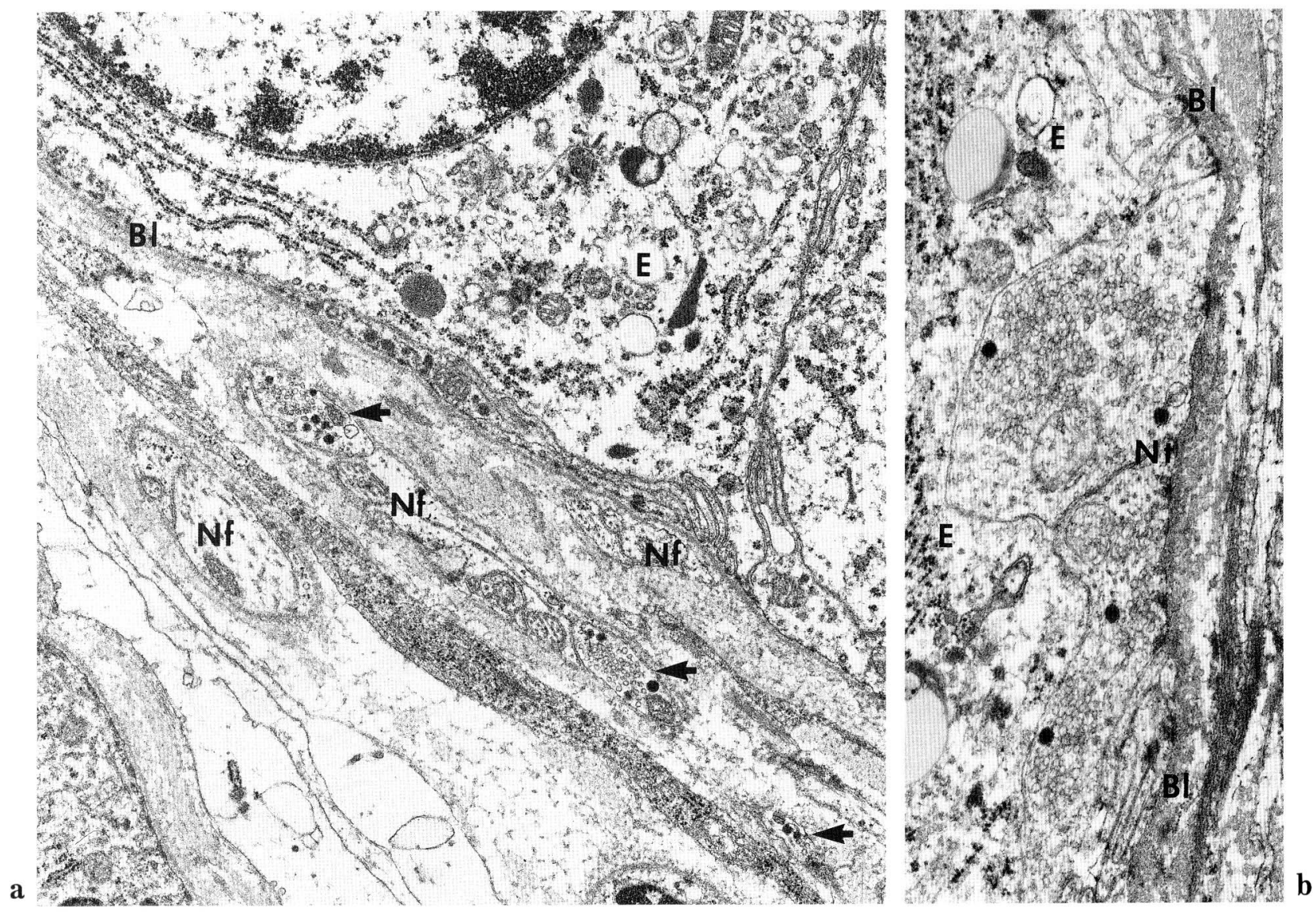

Fig. 12. Innervation of prostatic epithelium. a. Subepithelial nerve fibers $(N f)$ display terminals (arrow) with clear vesicles and larger dense granules. $E$ prostatic epithelium, $B l$ basal lamina. $\times 14,600$. b. Nerve terminals $(N t)$ are situated inside the basal lamina $(B l)$ in direct contact with the glandular epithelium $(E) . \times 25,000$

Figs. 13-18. Reaction of periurethral glandular tissue with FITC-conjugated lectins. Fig. 13. Granules of prostatic Type I cells react with WGA. Fig. 14. Prostatic Type II cells display varying affinities to GSA I, while capillaries react strongly and uniformly. Fig. 15. Granules of prostatic Type II cells are positive for MPA. Fig. 16. In the bulbourethral gland Type II cells bind SBA, while end pieces with Type I cells (arrow) are negative. Fig. 17. Strong reaction for WGA in mucous lining cells of a bulbourethral collecting space. Fig. 18. Material in bulbourethral Type II glandular cells gives off strong fluorescence. Note also positive reaction for MPA in basal lamina and connective tissue matrix. Fig. 13: $\times 560$, Figs. $14-18: \times 350$ 

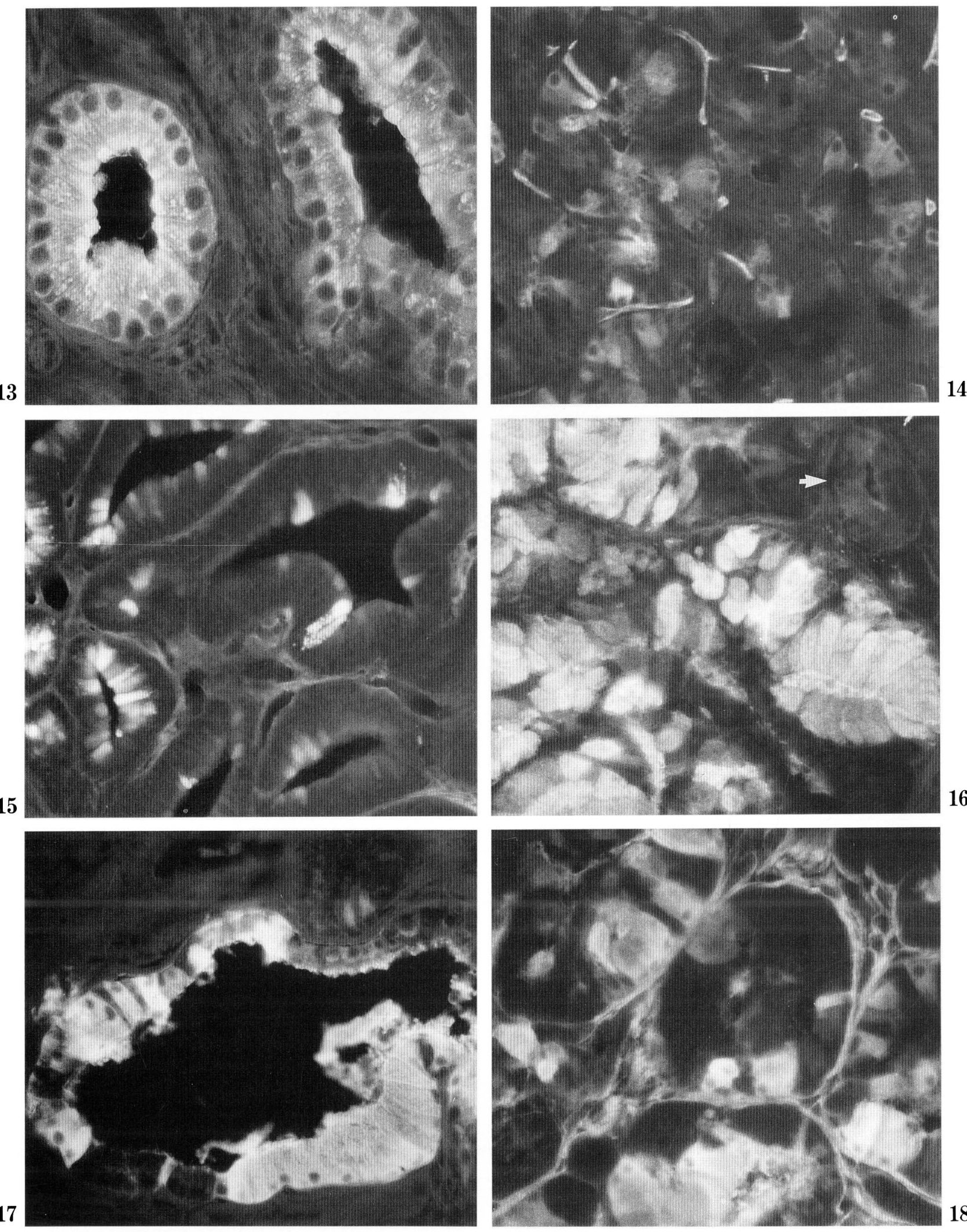

Figs. 13-18. Legends on the opposite page. 
Table 2. Reactions of the glandular epithelial cells of the periurethral glands in the water buffalo with FITCconjugated lectins.

\begin{tabular}{lcccc}
\hline Lectins & \multicolumn{2}{c}{ Prostate } & \multicolumn{3}{c}{ Bulbourethral glands } \\
& Type I & Type II & Type I & Type II \\
\hline Con A & ++ & ++ & + & - \\
DBA & - & ++ & - & - \\
SBA & + & $+++/-$ & - & $++/-$ \\
RCA I & + & ++ & - & - \\
WGA & ++ & $+++/-$ & $+/-$ & $+++/-$ \\
UEA I & ++ & +++ & $++/-$ & $+++/-$ \\
PNA & - & +++ & + & $++/-$ \\
GSA I & - & ++ & - & + \\
GSA II & - & $+++/-$ & - & $+++/-$ \\
MPA & - & +++ & - & $+/-$ \\
\hline
\end{tabular}

+++ : strong reaction, $++:$ moderate reaction, + : weak reaction, - : negative reaction, / - : partial reaction

The glycoprotein granules of Type I cells in the prostate contain sugars specific for binding Con A, SBA, RCA I, WGA and UEA I, while those of the bulbourethral glands react with Con A, WGA, UEA I and PNA.

The interstitial capillaries display a strong reaction with GSA I indicating the presence of $\alpha$ galactose.

\section{DISCUSSION}

Accessory glands which are derived from the epithelium of the urogenital sinus are phylogenetically old and exist in marsupials, monotremes and higher mammals. The periurethral glandular tissue in ruminants can serve as a general model for the differentiation of this complex in separate glandular structures as prostate and bulbourethral glands. According to this concept, the most primitive situation consists of a diffuse glandular layer around the entire pelvic urethra. The secretory epithelium displays Type I (specific) and Type II (mucous) cells in a roughly even distribution. Such a primitive situation (disseminate prostate only) is observed in some species of deer, although in the red deer a regional concentration of mucous cells in the caudal portion of the glandular layer is encountered (AUGHEY, 1969). In the goat and ram, the caudal periurethral glands have concentrated to form separate bulbourethral glands.
At the histological level, Type I and II cells are observed in the entire glandular complex, though Type I cells dominate within the cranial disseminate glands, and Type II cells within the bulbourethral glands (WroBEL, 1970, 1972; WroBEL and SiNOWATZ, 1985). The water buffalo represents a further step in macroscopical and histological differentiation. The cranial periurethral glands form a prostate body in the majority of animals. A prostate body was lacking in $24 \%$ of buffaloes examined in one study (EISSA, 1980). Between this prostate body and the welldeveloped bulbourethral glands a continuous glandular sheath (disseminate prostate) surrounds the pelvic urethra. Type I cells dominate in the prostate body and cranial half of the disseminate prostate, while Type II cells prevail in the caudal half and the bulbourethral glands. A still higher degree of regional specialization is found in the bull (DJANNATIAN, 1973), where the cranial periurethral glands always form a macroscopically distinct prostate body and where the bulbourethral glands no longer contain Type I cells but exclusively Type II mucus secreting cells.

Perfusion fixation of the periurethral glands resulted in the demonstration of epithelial peculiarities indicative of increased intercellular and transepithelial transport. Short apical intercellular secretory canaliculi with microvilli were observed. These were separated from the normal intercellular space by junctional complexes, which represent highly selective barriers (TRUMP et al., 1981). At the lateral cell surfaces a horizontally running intercellular transport and exchange system is developed. It consists of intercellular canaliculi with a dilated lumen or with interdigitating cytoplasmic processes. Exchange by microvesiculation is frequently observed between this transport system and the adjacent cells. In the basolateral position an intercellular horizontally running labyrinth of interdigitating or folded cell membranes increases the exchange area between cells and stroma. Similar devices for intercellular and transepithelial transport have also been observed in the bovine prostate following perfusion fixation (ABOUELMAGD and WROBEL, 1986).

Notions concerning the innervation of the periurethral glands are still controversial. JABONERO et al. (1963) reported in light microscopical observations that nerve fibers surrounding the end pieces may penetrate the basal lamina to establish neuroglandular contacts. SMITH and LEBEAUX (1970) and SHIMA (1973) described the human prostate as being innervated by cholinergic fibers via synapses "à distance". AUMÜLLER (1979), on the other hand, was not able 
to verify the aforementioned results at the ultrastructural level. However, in our material we observed with the electron microscope a network of unmyelinated fibers in very close contact with the secretory end pieces. In the prostate these nerves frequently perforate the basal lamina and terminate in the intercellular spaces, in a manner similar to that reported for the guinea-pig seminal vesicle (ALZUHAIR et al., 1975). The ultrastructure of these terminals in buffalo prostatic epithelium resembles that as described for salivary (JOHANSSON and LUND. BERG, 1981) and sweat glands (TAINIO and VAALASTI, 1988): the terminals contain small agranular vesicles and a few large dense-core vesicles and probably represent secretory cholinergic fibers.

Though the periurethral glandular complex is well-developed in the buffalo as in other ruminants, the exact role of prostatic and bulbourethral secretions in the reproduction process is poorly understood. Carbohydrates represent an important fraction of the periurethral glandular secretion. By means of substrate- and lectin-histochemistry, TSUKISE and YAMADA $(1984,1987 \mathrm{a}, \mathrm{b})$ were able to identify sialomucin, specific glycoproteins and at least two different types of glycoconjugates in the secretory granules of the goat prostate. Our studies in the buffalo confirm the existence of a diversified pattern of glycoconjugates. These glycoconjugates may be necessary for stabilization of the spermatozoan plasma membrane, or may serve as a source of energy for spermatozoa and have protective functions for the urethral epithelium (MILLETTE, 1977; KoEHLER, 1978, 1981; TSUKISE and YAMADA, 1981; HOLT, 1984; YAMADA, 1985).

Acknowledgements. We thank Mr. Mark MEIER for linguistic help, and Mrs. DASSLER, Mrs. SchIMMEL and Mr. SIEGERT for technical assistance.

\section{REFERENCES}

Abou-Elmagd, A. and K.-H. Wrobel: Zur Morphologie des sekretorischen Epithels im Prostatakörper des Rindes. Berl. Münch. Tierärztl. Wochenschr. 99: 279282 (1986).

Al-Zuhair, A., J. A. Gosling and J. S. Dixon: Observations on the structure and autonomic innervation of guinea-pig seminal vesicle and ductus deferens. J. Anat. 1: 81-93 (1975).

Aughey, E.: Histology and histochemistry of the male accessory glands of the red deer, Cervus elephus L. J. Reprod. Fert. 18: 399-407 (1969).
Aumüller, G: Prostate gland. In: (ed. by) G. AumülleR: Handbuch der mikroskopischen Anatomie des Menschen, Vol. VII/6. Prostate gland and seminal vesicles. Academic Press, Berlin-Heidelberg-New York-London, 1979 (p. 53-182).

DJannatian, M.: Histologische und histochemische Untersuchungen an der Prostata des Rindes vor und nach der Geschlechtsreife. Inaug. Diss. (Med.) Marburg, 1973.

DoRn, A. and H. G. Bernstein: Laborpraxis der Immunhistochemie. Gustav Fischer Verlag, Stuttgart, 1983.

Eissa, H. M. A.: Seasonal biological activity of the accessory genital glands of buffalo-bull. Thesis, Fac. Vet. Med., Cairo, 1980.

FAнmy, M. F. A. and A. M. H. Osman: Certain morphological investigations on the male genital organs of water buffalo as a guide for andrological diagnosis. IV. Accessory glands. Egypt. J. Vet. Sci. 9: 57-65 (1972).

Holt, W. V.: Membrane heterogeneity in the mammalian spermatozoon. Int. Rev. Cytol. 87: 159-194 (1984).

Jabonero, V., M. J. Genis and L. Santos: Beobachtungen über die osmium-zinkjodidaffinen Elemente der Vorsteherdrüse. Z. Mikrosk.-Anat. Forsch. 69: 167-194 (1963).

JoHansson, O. and J. M. LundBerg: Ultrastructural localization of VIP-like immunoreactivity in large dense-core vesicles of cholinergic-type nerve terminals in cat exocrine glands. Neuroscience 6: 847-862 (1981).

KARnovsky, M. J.: A formaldehyde-glutaraldehyde fixative of high osmolarity for use in electron microscopy. J. Cell. Biol. 27: 137-138 (1965).

KoEHLER, J. K.: The mammalian sperm surface: Studies with specific labeling techniques. Int. Rev. Cytol. 54: 73108 (1978).

- Lectins as probes of the spermatozoon surface. Arch. Androl. 6: 197-217 (1981).

Millette, C. F.: Distribution and mobility of lectin binding sites on mammalian spermatozoa. In: (ed. by) M. EDIDIN and M. H. JoHANSON: Immunobiology of gametes: Clinical and experimental immunoreproduction. Cambridge University Press, London, 1977 (p. 5171).

Moussa, M. H. G., A. B. A. Badawy, M. H. A. Kandil and Y. M. ShaHIN : Histological and histochemical studies of the accessory genital glands of buffalo-bull (Bubalis bubalis). Anat. Anz. 153: 429-439 (1983).

Osman, A. M. H.: Some clinical studies on the genital organs of buffalo-bull. Thesis, Fac. Vet. Med., Cairo, 1965.

REYNolds, E. G.: The use of lead citrate at high pH as an electron-opaque stain in electron microscopy. J. Cell. Biol. 17: 208-212 (1963).

Shima, M.: Studies on the innervation of the prostate. III. Prostatic contraction and fluid excretion in dog secretion on stimulation of various nerves innervating the prostate. Jap. J. Urol. 64: 539-554 (1973).

Smith, E. R. and J. Lebeaux: The mediation of the canine prostatic secretion provoked by hypogastric stimulation. Invest. Urol. 7 : 313-318 (1970). 
SPURR, A. R.: A low viscosity epoxy resin embedding medium for electron microscopy. J. Ultrastr. Res. 26: 31 (1969).

Tainio, H. and K. VaAlasti : Electron microscopic study on the innervation of human axillary sweat glands. Acta Histochem. 83: 167-177 (1988).

Trump, B. F., B. M. Heatrield and P. C. Phelps: The role of the cytoskeleton and related components in normal and neoplastic prostatic epithelium. In (ed. by) G. P. Murphy, A. A. Sandberg and J. P. KarR: The prostatic cell: Structure and function. Alan R. Liss Inc. New York, 1981 (Part A, p. 25-53).

Tsukise, A. and K. Yamada: The histochemistry of complex carbohydrates in the scrotum of the boar. Histochemistry 72: 511-521 (1981).

: Complex carbohydrates in the secretory epithelium of the goat prostate. Histochem. J. 16: 345-350 (1984). epithelium of the goat prostate. Histochem. J. 19: 345350 (1987a).

- Histochemistry of glycoconjugates in the secretory epithelium of the goat bulbourethral glands. Acta Anat. 129: 344-352 (1987b).

WROBEL, K.-H.: Untersuchungen zur Feinstruktur und Histochemie der Glandula bulbourethralis der Ziege. Z. Zellforsch. 108: 582-595 (1970).

: Histochemische Untersuchungen am Prostataparenchym der Ziege. Zentralbl. Vet. Med. C 1: 64-72 (1972).
Wrobel, K.-H. and F. Sinow ATZ: Vergleichende Studien an den Anhangsdrüsen der männlichen Urethra. Acta Histochem., Suppl. 31: 193-200 (1985).

Wrobel, K.-H., F. SinOWATZ and P. KUGLER: Zur funktionellen Morphologie des Rete testis, der Tubuli recti und der Terminalsegmente der Tubuli seminiferi des geschlechtsreifen Rindes. Zentralbl. Vet. Med. C 7: 320335 (1978).

YAMADA, K.: Bulbourethral gland. In: (ed. by) K. OGaWA Human histology, Vol. 6. Endocrine and reproductive organs. Asakusa Shoten, Tokyo, 1985 (p. 325-330).

Yamada, K. and S. Shimizu: The histochemistry of galactose residues of complex carbohydrate as studied by peroxidase-labelled ricinus communis agglutinin. Histochemistry 53: 143-156 (1977).
Prof. Karl-Heinz WROBEL

Institute of Anatomy

University of Regensburg

Universitätsstraße 31

D-8400 Regensburg

Federal Republic of Germany 